\title{
Antifreeze Acute Intoxication: Hemodialysis in Two German Sheppard Dogs
}

\author{
Bogdan Alexandru VIŢĂLARU ${ }^{*}$, Ştefăniță Bogdan BĂLĂŞCĂU ${ }^{1}$ \\ ${ }^{1}$ Department of Clinical Sciences, Faculty of Veterinary Medicine, Bucharest, Romania \\ ${ }^{*}$ Corresponding author: alexandrumv@yahoo.com
}

Bulletin UASVM Veterinary Medicine 72(2) / 2015,

Print ISSN 1843-5270; Electronic ISSN 1843-5378

DOI:10.15835/buasvmcn-vm: 11636

\begin{abstract}
Hemodialysis (HD) is a highly effective therapeutic method employed to remove toxic by-products and metabolites from the body when this task can no longer be performed by the kidneys that are either permanently damaged, as in chronic kidney failure, or need time and proper treatment to recover from other diseases of the kidney itself or pathologies that may affect the renal function as they progress.

Hemodialysis uses the dialyzer or "artificial kidney" which is the basis for renal replacement extracorporeal therapy. Within the dialyzer, blood and dialysate are separated by a semi permeable membrane, which allows the free passage of water and small molecules. The movement of molecules through the membrane is mainly driven by two forces: diffusion and convection.

The study describes the evolution and follows the dynamic of the biomarkers in 2 dogs suffering from kidney failure, subsequent to acute intoxication with antifreeze. Both subjects were admitted in our Centre 28 hours after ingestion and after i.v. drip of commercial alcohol.

Hemodialysis was performed in two dogs, brother and sister, six months of age, using a BBraun Dialog+ hemodialysis machine. Blood samples were taken from each dog before and after the procedure and then twice in the next ten days, in order to monitor the ionogram, creatinine and BUN levels. Also, before starting the procedure, the patients underwent an ultrasound examination to evaluate the kidneys and to exclude other problems that would prevent this treatment. We have also collected urine in order to perform an accurate urine sediment analysis. Both patients exhibited a full recovery after 5 hemodialysis sessions, showing that the procedure was able to remove the toxins and to restore the renal function, a fact also proved by the levels of metabolites involved in the clinical evolution.

Blood samples collected twice in the next 10 days showed a complete recovery of the renal function in both patients.

Hemodialysis is highly effective in the removal of ethylene glycol and its metabolites from the blood. Hemodialysis also has the added benefit of correcting other metabolic disturbances or of supporting deteriorate kidney function.
\end{abstract}

Keywords: hemodialysis, dogs, intoxication, kidney, peritoneal.

\section{INTRODUCTION}

Hemodialysis (HD) is a highly effective therapeutic method employed to remove toxic byproducts and metabolites from the body when this task can no longer be performed by the kidneys that are either permanently damaged, as in chronic kidney failure, or need time and proper treatment to recover from other diseases of the kidney itself or pathologies that may affect the renal function as they progress (Moreau et al.,1998).

Hemodialysis uses the dialyzer or "artificial kidney" which is the basis for renal replacement extracorporeal therapy (Acierno and Labato, 2011). Within the dialyzer, blood and dialysate are separated by a semi permeable membrane, which allows the free passage of water and small 
molecules. The movement of molecules through the membrane is mainly driven by two forces: diffusion and convection (Moreau et al.,1998).

\section{MATERIALS AND METHODS}

The objectives of the current study are to emphasise the importance of the role played by hemodialysis in the treatment of acute poisoning with antifreeze. As we already know the seriousness of this intoxication, we are trying to prove the efficiency of the immediate treatment in this situation. Both patients were admitted in our Centre 28 hours after ingestion and after an i.v. drip with commercial alcohol. Both dogs have been reported by the owner as being seen drinking antifreeze. The female ingested more poison, being the one that broke the antifreeze recipient. They were both stable, normothermic and conscious. This study describes the evolution and follows the dynamic of the biomarkers in these two dogs suffering from kidney failure, subsequent to acute intoxication with antifreeze (Winchester el al., 2007).

Hemodialysis was performed in two German Sheppard dogs, brother and sister, six months of age, using a BBraun Dialog+ hemodialysis machine. The male was $19 \mathrm{~kg}$ and the female, $16 \mathrm{~kg}$. Blood samples were taken from each dog before and after every procedure and then twice in the next ten days, in order to monitor the creatinine and BUN levels.

Also, before starting the procedure, the patients underwent an ultrasound examination to evaluate the kidneys and to exclude other problems that would prevent this treatment. There were no other modifications in the abdominal organs. We have also collected urine for performing an accurate urine sediment analysis. Urine test for both patients were inconclusive at the admission day. Clinical exam was performed at the admission (Tab. 1).

Hemodialysis was performed using a double lumen $12 \mathrm{Fr} / 20 \mathrm{~cm}$ central venous catheter, placed into the left jugular vein using light sedation with butorphanol $0.2 \mathrm{mg} / \mathrm{kg}$ i.v. and propofol $5 \mathrm{mg} / \mathrm{kg}$ i.v. and local anaesthesia using lidocaine in both patients (Costea and Vițălaru, 2015; Bălășcău el al., 2015). After a complete evaluation, we performed 5 hemodialysis sessions using an A/V set for Dialog-low flux dialyzer, volume $142 \mathrm{ml}$ with dialysate composition set to: bicarbonate $32 \mathrm{mmol} / \mathrm{L}$, Na $138 \mathrm{mmol} / \mathrm{L}, \mathrm{K} 2 \mathrm{mmol} / \mathrm{L}$ and a dialysate flow of $500 \mathrm{ml} / \mathrm{min}$ during the next 6 days.

During the first session, both dogs were submitted to a general protocol of 1 hour, bicarbonate $14.0 \mathrm{mS} / \mathrm{cm}, 200 \mathrm{ml} / \mathrm{h}$ ultrafiltration. For the next five days we increased the duration of hemodialysis with 1 hour/session until we reached 4 hours/ session (session 4 and 5) and after 6 days we decided to discontinue the treatment because of the full recovery of both patients.

During hemodialysis, both dogs were treated to arrest the gastric symptoms (vomiting and gastric ulcerations) using i.v. Ondansetron $(0.22$ $\mathrm{mg} / \mathrm{kg}$ bid) and ranitidine (2 $\mathrm{mg} / \mathrm{kg}$ bid). During the treatment, they were also fed only with renal diet food and they received Azodyl 3 times a day.

\section{RESULTS AND DISCUSSION}

Both patients exhibited a full recovery after 5 hemodialysis sessions, showing that the procedure was able to remove the toxins and to restore the renal function, a fact proved also by the levels of metabolites involved in the clinical evolution.

Both BUN and creatinine had a decreasing pathway and, after 5 hemodialysis sessions (Tab. 2, Fig. 1), both patients exhibited a complete recovery of the renal function, appetite, general status, with no vomiting episodes.

Blood samples collected after the last procedure and twice in the next 10 days were used to reveal the creatinine and BUN levels. They showed complete recovery of the renal function in both patients in the next 14-21 days (Moreau et al., 1998)

Tab. 1. General data of both patients in treatment of the acute antifreeze poisoning

\begin{tabular}{cccccccc}
\hline $\begin{array}{c}\text { Data } \\
\text { Patient }\end{array}$ & Breed & $\begin{array}{c}\text { Age } \\
\text { (months) }\end{array}$ & Weight $(\mathrm{kg})$ & $\begin{array}{c}\text { General } \\
\text { status }\end{array}$ & Vomiting & $\begin{array}{c}\text { Temperature } \\
\left({ }^{\circ} \mathrm{C}\right)\end{array}$ & Appetite \\
\hline Thor ${ }^{\lambda}$ & German Sheppard & 6 & 19 & Present & +++ & 37.5 & ++ \\
\hline Mora $q$ & German Sheppard & 6 & 16 & Present & +++ & 38.4 & +++ \\
\hline
\end{tabular}


The urine testes were inconclusive because of the fact that they here treated with alcohol i.v. immediately after the ingestion, this fact being supported by the Acierno and Labato, 2011 in their researches.

Both dogs were released under strict medical control with renal diet food and they both received Azodyl 3 times a day for the next 21 days after hemodialysis.

\section{CONCLUSION}

Hemodialysis is a highly effective treatment in patients intoxicated with ethylene glycol, being able to remove the toxin and its metabolites from the blood.

Hemodialysis also has the added benefit of correcting other metabolic disturbances and supporting the kidney function during the recovery.

Tab. 2. Evolution of BUN and Creatinine levels during the treatment, before and after each treatment

\begin{tabular}{|c|c|c|c|c|c|c|c|c|c|c|c|c|c|c|c|c|}
\hline \multirow{3}{*}{ Patient } & \multicolumn{4}{|c|}{ Day 1} & \multicolumn{4}{|c|}{ Day 2} & \multicolumn{4}{|c|}{ Day 3} & \multicolumn{4}{|c|}{ Day 4} \\
\hline & \multicolumn{2}{|c|}{$\begin{array}{c}\text { BUN } \\
(\mathrm{mg} / \mathrm{dl})\end{array}$} & \multicolumn{2}{|c|}{$\begin{array}{c}\text { Crea } \\
(\mathrm{mg} / \mathrm{dl})\end{array}$} & \multicolumn{2}{|c|}{$\begin{array}{c}\text { BUN } \\
(\mathrm{mg} / \mathrm{dl})\end{array}$} & \multicolumn{2}{|c|}{$\begin{array}{c}\text { Crea } \\
(\mathrm{mg} / \mathrm{dl})\end{array}$} & \multicolumn{2}{|c|}{$\begin{array}{c}\mathrm{BUN} \\
(\mathrm{mg} / \mathrm{dl})\end{array}$} & \multicolumn{2}{|c|}{$\begin{array}{c}\text { Crea } \\
(\mathrm{mg} / \mathrm{dl})\end{array}$} & \multicolumn{2}{|c|}{$\begin{array}{c}\text { BUN } \\
\text { (mg/dl) }\end{array}$} & \multicolumn{2}{|c|}{$\begin{array}{c}\text { Crea } \\
(\mathrm{mg} / \mathrm{dl})\end{array}$} \\
\hline & $\mathrm{B}$ & $\mathrm{A}$ & $\mathrm{B}$ & $\mathrm{A}$ & $\mathrm{B}$ & $\mathrm{A}$ & $\mathrm{B}$ & $\mathrm{A}$ & $\mathrm{B}$ & $\mathrm{A}$ & $\mathrm{B}$ & $\mathrm{A}$ & $\mathrm{B}$ & $\mathrm{A}$ & $\mathrm{B}$ & A \\
\hline Thor ${ }^{\lambda}$ & 75 & 46 & 4.2 & 2.1 & 71 & 24 & 3.6 & 1.6 & 46 & 18 & 3.7 & 2 & 41 & 17 & 3.9 & 1.9 \\
\hline Mora 9 & 95 & 59 & 9.1 & 3.6 & 80 & 40 & 5.5 & 2.7 & 71 & 26 & 4.7 & 2.4 & 63 & 24 & 4.4 & 2.2 \\
\hline \multirow{3}{*}{ Patient } & \multicolumn{4}{|c|}{ Day 5} & \multicolumn{4}{|c|}{ Day 6} & \multicolumn{4}{|c|}{ Day 16} & & & & \\
\hline & \multicolumn{2}{|c|}{$\begin{array}{c}\text { BUN } \\
(\mathrm{mg} / \mathrm{dl})\end{array}$} & \multicolumn{2}{|c|}{$\begin{array}{c}\text { Crea } \\
(\mathrm{mg} / \mathrm{dl})\end{array}$} & \multirow{2}{*}{\multicolumn{2}{|c|}{$\begin{array}{c}\text { BUN } \\
(\mathrm{mg} / \mathrm{dl})\end{array}$}} & \multirow{2}{*}{\multicolumn{2}{|c|}{$\begin{array}{c}\text { Crea } \\
(\mathrm{mg} / \mathrm{dl})\end{array}$}} & \multirow{2}{*}{\multicolumn{2}{|c|}{$\begin{array}{c}\text { BUN } \\
(\mathrm{mg} / \mathrm{dl})\end{array}$}} & \multirow{2}{*}{\multicolumn{2}{|c|}{$\begin{array}{c}\text { Crea } \\
\text { (mg/dl) }\end{array}$}} & & & & \\
\hline & B & $\mathrm{A}$ & B & $\mathrm{A}$ & & & & & & & & & & & & \\
\hline Thor ${ }^{\lambda}$ & 32 & 13 & 2.6 & 1.4 & 2 & 6 & 2. & 8 & 1 & 1 & & 7 & & & & \\
\hline Mora 9 & 54 & 20 & 3.9 & 2.0 & 1 & & 2. & 0 & 1 & 1 & & 4 & & & & \\
\hline
\end{tabular}
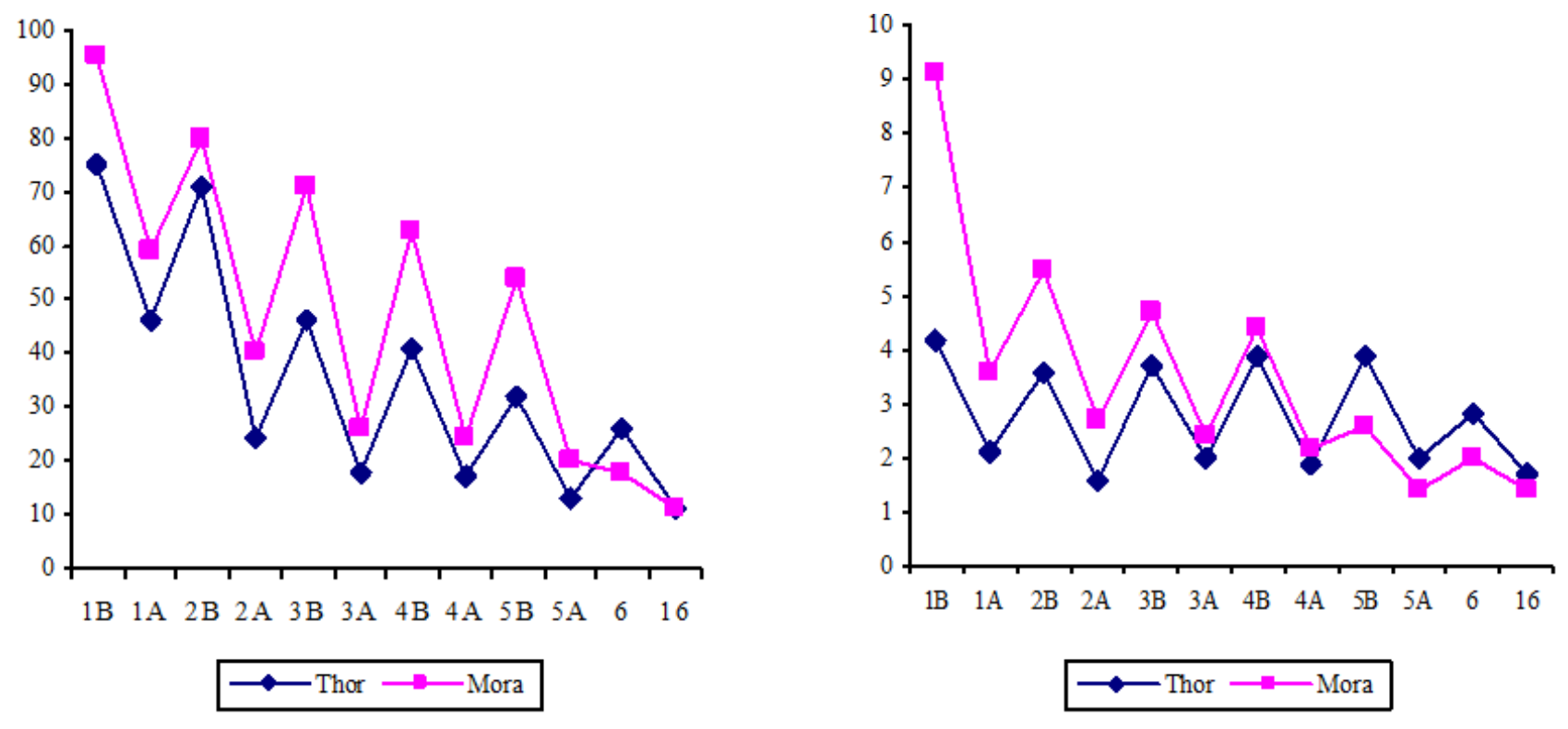

Fig. 1. Left - The evolution of BUN in both cases. Right - The evolution of creatinine in both cases (B - before hemodialysis, A - after hemodialysis) 
The sooner the patient is submitted to hemodialysis, the better are the results and the recovery is complete.

The recovery is strictly connected to the volume of ethylene glycol ingested.

\section{REFERENCES}

1. Acierno, MJ, Labato Mary (2011). Kidney Diseases and Renal Replacement Therapies, An Issue of Veterinary Clinics: Small Animal Practice, Elsevier-Saunders, Ottawa

2. Moreau CL, Kern SW, Tomaszewski CA (1998). Glycolate kinetics and hemodialysis clearance in ethylene glycol poisoning. J Toxicol Clin Toxicol;36: 659-66.

3. Winchester JF, Boldur A, Oleru C (2007). Use of dialysis and hemoperfusion in treatment of poisoning. In: Daugirdas
JT, Blake PG, Ing TS, editors. Handbook of dialysis. $4^{\text {th }}$ edition. Philadelphia: Wolters Kluwer. p. 300.

4. Bălășcău ȘB, Bociu A, Ivașcu C, Micșa C, Vițălaru BA (2015). Choosing the central venous catheter in order to perform hemodialysis in dog, Journal of Biotechnology, Volume 208, Supplement, S42

5. Bălășcău SB, Bociu A, Ivașcu C, Micșa C, Vițălaru BA (2015). Heparinization of the central venous catheter in dogs undergoing hemodialysis, Journal of Biotechnology, Volume 208, Supplement, S42

6. Costea Ruxandra, Vițălaru BA (2015). Propofol induction anesthesia for central venous catheterization in dogs with renal failure, Journal of Biotechnology, Volume 208, Supplement, S42-S43 